\title{
Pd-Ia exerts anti-inflammatory effects by activating PPAR- $\alpha$ in human umbilical vein endothelial cells
}

\author{
Chang $\mathrm{H}^{1,2,3 \# *}$, Zhang $\mathrm{J}^{2}$, Yang $\mathrm{C}^{2,3}$ and $\mathrm{Qi} \mathrm{Z}^{2 \# *}$ \\ ${ }^{1}$ Department of Geriatrics, Xiang' an Hospital of Xiamen University, Xiang'an East Road, Xiamen 361101, China \\ ${ }^{2}$ School of Medicine, Xiamen University, Xiang'an South Road, Xiamen 361102, China \\ ${ }^{3}$ Xiamen Cardiovascular Hospital of Xiamen University, Hubin South Road NO. 205, Xiamen, 361004, China \\ \#Both Contributed Equally
}

\begin{abstract}
Pd-Ia (dl-praeruptorin A), isolated from Chinese traditional herbal medicine Qian-Hu, has been linked to cardiovascular diseases because of its effective role on left ventricular dysfunction, exhibit anti-inflammatory properties through reducing the level of pro-inflammatory factors in ischemia/reperfusion myocardium. However, the potential roles and possible mechanisms in endothelial cells inflammatory response have yet to be fully clarified. In the present study, human umbilical vein endothelial cells (HUVECs) were selected to perform in vitro assays. Pd-Ia significantly reduced the mRNA expression of pro inflammatory cytokines and chemokines, including tumor necrosis factor $\alpha$ (TNF- $\alpha$ ), interleukin (IL) $1 \beta$, IL 6, IL 8, monocyte chemoattractant protein 2 (MCP-2) and vascular adhesion molecule 1 (VCAM 1) that were upregulated by LPS stimulation. Pd-Ia selectively increased peroxisome proliferator-activated receptor- $\alpha$ (PPAR- $\alpha$ ) expression and enhanced the phosphorylation of PPAR- $\alpha$ that were downregulated by LPS. Furthermore, knockdown of PPAR- $\alpha$ by siRNA abrogated the effects of Pd-Ia on pro inflammatory cytokines TNF- $\alpha$ and IL $1 \beta$ expression in LPS stimulated HUVECs. Additionally, Pd-Ia decreased the LPS upregulated NF- $\kappa$ B 65 phosphorylation at tested timepoints, which was abolished by PPAR- $\alpha$ antagonist MK886. These results demonstrated that Pd-Ia inhibited the pro inflammatory genes expression through activating PPAR- $\alpha$ and suppressing NF- $\kappa$ B activity. Thus, Pd-Ia may have the potential of being developed as an anti-inflammatory agent.
\end{abstract}

\section{Introduction}

The inflammatory response of endothelial cells is critical for the pathogenesis of various diseases, such as endotoxic shock, cancer, thrombosis, atherosclerosis and diabetes mellitus. Inflammatory activation of the endothelium has been shown to decrease its vasomodulatory ability and antithrombotic properties, contributing to the pathogenesis of atherosclerosis [1]. Chronic inflammation in endothelial cells produces a variety of inflammatory mediators to exacerbate endothelial dysfunction, which plays a dominant role in atherosclerosis, hypertension and diabetes-induced vasculopathy and vascular remodelling [2-4]. Endothelial cells are activated to release inflammatory mediators such as TNF- $\alpha$ and IL- $1 \beta$, chemokines (MCP1 and IL-8), adhesion molecules (ICAM-1 and VCAM-1) [5,6]. In turn, the release of inflammatory factors, chemokines and adhesion molecules as well as coagulation factors activates the vascular endothelial cells and subsequently promotes the vascular endothelial injury [7]. Lipopolysaccharide (LPS) has been identified as one of the strongest stimulators that target the endothelium, LPS induce the morphological damage, reduce cell viability of HUVECs and increase TNF- $\alpha$, IL-8, IL$1 \beta$ and MCP- 1 expression $[6,8,9]$. Therefore, endothelial cells are one of the active participants in regulation of inflammatory reactions.

Pd-Ia (dl-praeruptorin A), isolated from Chinese traditional herbal medicine Qian-Hu, has a long history of application for the treatment of cough with thick sputum and dyspnea, non-productive cough and upper air-way infections in traditional medicinal practice [10,11]. Our previous study had revealed that Pd-Ia had cardioprotective action and relieved inflammatory reaction and apoptosis in rat isolated ischemia- reperfusion myocardium through inhibiting the activity of
TNF- $\alpha$, interleukin-6, Fas, bax, bcl-2 and NF- $\kappa$ B expression [12, 13]. Meanwhile, Pd-Ia decreased cardiomyocyte surface area and protein synthesis, inhibited the expression of $\mathrm{Bax} / \mathrm{Bcl} 2$ and atrial natriuretic factor (ANF) activity in cultured neonatal cardiomyocytes [14]. Yet the understanding of the mechanism of anti-inflammatory effects of Pd-Ia remains limited.

Peroxisome proliferator-activated receptors (PPARs) belong to the superfamily of nuclear receptors which are ligand-activated transcription factors. Three different PPAR subtypes have been identified: PPAR $\alpha, \operatorname{PPAR} \beta / \delta, \operatorname{PPAR} \gamma[15]$. PPAR- $\alpha$ has been shown to play a critical role in regulating inflammatory processes [16], PPARa activation inhibits vascular smooth muscle proinflammatory responses, attenuating the development of atherosclerosis, involved in endothelial cell functions and regulation of inflammation $[17,18]$. Therefore, PPAR- $\alpha$ behaves as a modulator of both acute and chronic inflammation and became a rational potential therapeutic target for the treatment of inflammatory disorders [19,20].

${ }^{*}$ Correspondence to: He Chang, professor, Department of Geriatrics, Xiang' an Hospital of Xiamen University, Xiang'an East Road, Xiamen 361101, China. E-mail: changhe@xmu.edu.cn

Zhi Qi, professor, School of Medicine, Xiamen University, Xiang'an South Road, Xiamen 361102, China. E-mail: qizhi@xmu.edu.cn

Key words: Pd-Ia, PPAR- $\alpha$, HUVECs, pro-inflammatory genes, $N F-\kappa B$

Received: December 19, 2018 ; Accepted: January 14, 2019; Published: January 16,2019 
However, whether Pd-Ia may act at PPAR- $\alpha$ to play the antiinflammatory role is not well understood. In this study, we investigated the effects of Pd-Ia on LPS-induced inflammatory responses. We found that PPAR- $\alpha$ plays a critical role in mediating the anti-inflammatory effects of Pd-Ia in LPS-stimulated HUVECs.

\section{Materials and methods}

\section{Reagents and antibodies}

Pd-Ia was kindly provided by Prof. Toru Okuyama (Meiji College of Pharmacy, Japan) [10]. Dulbecco's Modified Eagle Medium (DMEM), fetal bovine serum (FBS) and antibiotics (penicillin/streptomycin) were purchased from Hyclone. Recombinant human basic fibroblast growth factor (FGF) was purchased from Peprotech Inc. RevertAidTM First Strand cDNA Synthesis Kit was purchased from Fermentas. SYBR ${ }^{\circ}$ Premix Ex TaqTM II was purchased from TaKaRa. TRIzol reagent, Lipofectamine $^{\mathrm{m}}$ RNAiMAX transfection reagent, siRNA 005, 006, 007 specific for PPAR- $\alpha$ (stealth RNAi select) and negative control siRNA (12935-200) were purchased from Invitrogen. LPS, DMSO and PPAR- $\alpha$ antagonist MK886 were purchased from Sigma.

\section{Cell culture}

Human umbilical vein endothelial cells (HUVECs) were harvested and isolated from fresh healthy volunteer maternal newborn umbilical cords. This study was performed in accordance with the Helsinki Declaration and approval of the Ethical Committees of School of Medicine, Xiamen University and Xiamen Cardiovascular Hospital. All subjects have consented to this study. HUVECs were digested by trypsogen and kept in $0.2 \%$ gelatin-coated cell culture dishes in DMEM medium containing 15\% FBS (fetal bovine serum), $5 \mathrm{ng} / \mathrm{ml}$ FGF(fibroblast growth factor), $100 \mathrm{U} / \mathrm{ml}$ penicillin, and $100 \mu \mathrm{g} / \mathrm{ml}$ streptomycin sulfate. HUVECs were seeded onto 6-well plates at $1 \times 106$ cells/well concentration in $2 \mathrm{ml}$ DMEM medium under a humidified $5 \%$ CO2 atmosphere to $80 \%$ confluency. 2-6 generations of Cells were used in the experiments.

\section{Quantitative real-time RT-PCR}

RNA was extracted using TRIzol reagent and cDNA was obtained using RevertAidTM First Strand cDNA Synthesis Kit according to the manufacturer's instructions. Specific primers were designed using Primer Express 3.0 software (Table 1). Real-time PCR was performed with the 7300 Real Time PCR System (Applied Biosystems) and SYBR Green (TaKaRa). The cycling program was set as follows: thermal activation for $30 \mathrm{~s}$ at $95^{\circ} \mathrm{C}$ and 40 cycles of PCR (melting for $5 \mathrm{~s}$ at $95^{\circ} \mathrm{C}$, followed by annealing/extension for $31 \mathrm{~s}$ at $60^{\circ} \mathrm{C}$ ). Relative expression normalized to the internal control GAPDH was assessed by comparative analysis of the quantitative real-time PCR results using the $2^{-\Delta \Delta \mathrm{CT}}$ method [21].

\section{ELISA}

The concentration of TNF- $\alpha$, IL- $1 \beta$, IL- 6 and IL- 8 in the culture supernatants was measured by ELISA kit (R\&D) according to manufacturer's instructions.

\section{Western blot analysis}

HUVECs were homogenized on ice in lysis buffer $(8 \mathrm{~mol} / \mathrm{L}$ urea, $1 \mathrm{mmol} / \mathrm{L}$ dithiothreitol, $1 \mathrm{mmol} / \mathrm{L}$ EDTA, $50 \mathrm{mmol} / \mathrm{L}$ Tris- $\mathrm{HCl}, \mathrm{pH}$ $=8.0$ ), supplemented with a proteinase inhibitor cocktail (Sigma) and sonicated three times for $10 \mathrm{~s}$ on ice. The protein in the samples was quantified by Bradford's method. Each protein in the sample
Table. 1 Primer sequences for quantitative real-time PCR assay

\begin{tabular}{|c|c|c|}
\hline \multirow{3}{*}{$\begin{array}{l}\text { Gene } \\
\text { TNF } \alpha\end{array}$} & \multicolumn{2}{|c|}{ Primer } \\
\hline & Forward & 5' GTG ACA AGC CTG TAG CCC ATG TT 3' \\
\hline & Reverse & 5' TTA TCT CTC AGC TCC ACG CCA TT 3' \\
\hline \multirow[t]{2}{*}{ IL-6 } & Forward & 5' AAG CCA GAG CTG TGC AGA TGA GTA 3' \\
\hline & Reverse & 5' TGT CCT GCA GCC ACT GGT TC 3' \\
\hline \multirow[t]{2}{*}{ IL-1 $\beta$} & Forward & 5' TGA TGG CTT ATT ACA GTG GCA ATG 3' \\
\hline & Reverse & 5' GTA GTG GTG GTC GGA GAT TCG 3' \\
\hline \multirow[t]{2}{*}{ IL-8 } & Forward & 5' ACA CTG CGC CAA CAC AGA AAT TA 3' \\
\hline & Reverse & 5' TTT GCT TGA AGT TTC ACTG GCA TC3' \\
\hline \multirow[t]{2}{*}{ PPAR $\alpha$} & Forward & 5' CCA TCG GCG AGG ATAG TTC TG 3' \\
\hline & Reverse & 5' TCT ACA TTC GAT GTT CAA TGC TCC A 3' \\
\hline \multirow[t]{2}{*}{ PPAR $\beta$} & Forward & 5' AAG GCA TCG GGC TTC CAC TA 3' \\
\hline & Reverse & 5' GCA CTT CTG GAA GCG GCA GTA 3' \\
\hline \multirow[t]{2}{*}{ PPAR } & Forward & 5' TGG AAT TAG ATG ACA GCG ACT TGG 3' \\
\hline & Reverse & 5' CTG GAG CAG CTT GGC AAA CA 3' \\
\hline \multirow[t]{2}{*}{ GAPDH } & Forward & 5' GCA CCG TCA AGG CTG AGA AC 3' \\
\hline & Reverse & 5' TGG TGA AGA CGC CAG TGG A 3' \\
\hline VCAM-1 & $\begin{array}{l}\text { Forward } \\
\text { Reverse }\end{array}$ & $\begin{array}{l}\text { 5' TCC CTA CCA TTG AAG ATA CTG GAAA 3' } \\
\text { 5' GCT GAC CAA GAC GGT TGT ATC TC 3' }\end{array}$ \\
\hline MCP-2 & $\begin{array}{l}\text { Forward } \\
\text { Reverse }\end{array}$ & $\begin{array}{l}\text { 5' GCT CAT AGC TGT CCC TGT CA 3' } \\
5^{\prime} \text { CAT ACC CTG CTT GGT CTG G 3' }\end{array}$ \\
\hline
\end{tabular}

was separated by $10 \%$ SDS-PAGE gels and transferred to the PVDF membrane (Millipore, USA). The membranes were preincubated with 5\% skim milk in PBS containing 0.05\% Tween 20 for $1 \mathrm{~h}$, then incubated by either anti-PPAR- $\alpha$ (1:1000, Abcam) or anti-phosphoPPAR- $\alpha$ (1:1000, Abcam) or anti- $\beta$-actin (1:1000, Epitomics) or anti-GAPDH (1:1000, Epitomics/Abcam) or anti-phospho-NF- $\mathrm{B}$ p65(1:1000, Abcam) overnight at $4^{\circ} \mathrm{C}$. Afterwards the membranes were washed in PBS containing $0.05 \%$ tween 20 , followed by incubation with secondary antibody horseradish peroxidase-conjugated goat antirabbit IgG (Jackson) or goat anti- mouse IgG (1:1000, lianke Beijing) for $1 \mathrm{~h}$ at room temperature. The immunoreactivity was visualized by an enhanced chemiluminescence (ECL) advanced kit (Millipore). Densitometric analyses were performed with Image J software.

\section{Cell transfections}

HUVECs were transfected in Opti-MEM with Lipofectamine RNAiMAX according to the manufacturer's protocol. For transfection, all siRNAs (PPAR- $\alpha$ siRNA 005, siRNA 006, siRNA 007 or the negative control) were re-suspended to a final concentration of $20 \mathrm{nM}$. After 24 $\mathrm{h}$ incubation, the transient transfected cells were treated with $1 \mu \mathrm{g} / \mathrm{ml}$ LPS and $40 \mu \mathrm{M}$ Pd-Ia for $24 \mathrm{~h}$. Relative expression of TNF- $\alpha$ and IL- $1 \beta$ was assessed by Quantitative Real-time PCR.

\section{Statistical analysis}

Experimental data are presented as mean \pm SEM. Differences were analyzed by one-way ANOVA followed by Fisher's least significant difference test. A value of $\mathrm{p}<0.05$ was regarded as significant.

\section{Results}

\section{Pd-Ia inhibited pro-inflammatory genes expression in LPS-} stimulated HUVECs

To evaluate the effects of Pd-Ia on LPS-induced inflammatory responses, we determined the pro-inflammatory genes expression 
in LPS-stimulated HUVECs. HUVECs were treated with LPS and different concentrations of Pd-Ia for $24 \mathrm{~h}$. The LPS stimulation significantly increased the mRNA expression of pro-inflammatory cytokines TNF- $\alpha$, IL- $1 \beta$, IL- 6 , chemokine IL-8,MCP- 2 and adhesion molecular VCAM-1 (Figure 1). Pd-Ia at concentration of 10, 20 and $40 \mu \mathrm{M}$ could dose- dependently decreased the mRNA levels of TNF- $\alpha$, IL-1 $\beta$ and IL-6 (Figure 1), The mRNA levels of IL-8, MCP-2 and VCAM-1 were significantly decreased by Pd-Ia, but not in a dosedependent manner (Figure 1). Consistent with mRNA expression, the protein levels of TNF- $\alpha$, IL- $1 \beta$, IL- 6 , IL- 8 that were upregulated upon LPS stimulation in culture supernatants were also decreased by Pd-Ia (Figure 2). These results suggested that Pd-Ia exert anti-inflammatory effects through inhibiting pro-inflammatory genes expression in LPSstimulated HUVECs.

Pd-Ia upregulates PPAR-a expression and enhances its phosphorylation in LPS-stimulated HUVECs

Nuclear receptors superfamily PPARs, including PPAR- $\alpha$, PPAR$\beta / \delta$ and PPAR- $\gamma$, are involved in the inflammatory responses in a variety of cell types [22,23]. To investigate which nuclear receptor was associated with the anti-inflammatory effects of Pd-Ia, HUVECs were treated with LPS and different concentrations of Pd-Ia for 24h. LPS stimulation significantly downregulated the mRNA level of PPAR- $\alpha$ and Pd-Ia treatment dose-dependently increased the PPAR- $\alpha$ level (Figure 3). The expression of PPAR- $\beta$ was no changed by LPS stimulation and Pd-Ia treatment (Figure 3). LPS stimulation
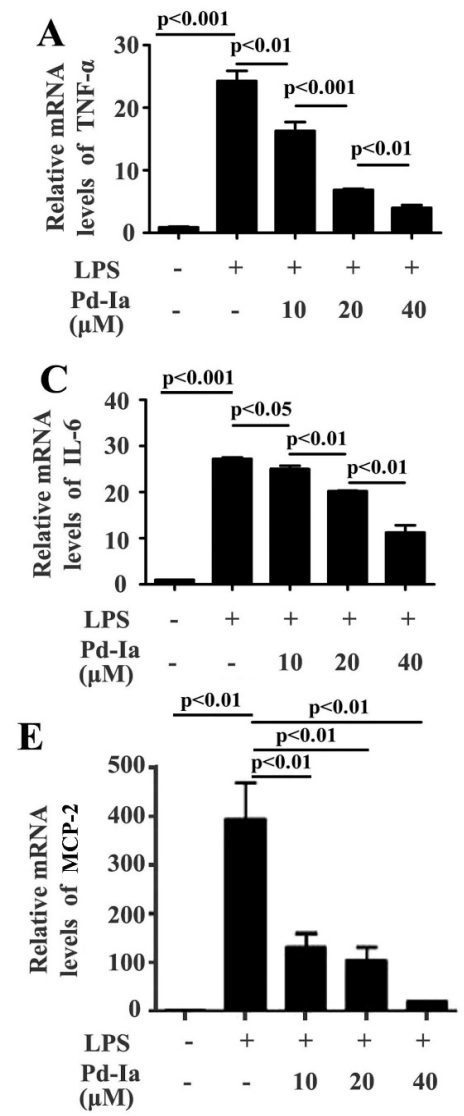

Figure 1. The mRNA expression of pro-inflammatory genes in LPS-stimulated HUVECs. (A) The relative mRNA levels of TNF- $\alpha$, (B) IL-1 $\beta$, (C) IL-6, (D) IL-8, (E) MCP-2 and (F) VCAM-1 were detected by quantitative real-time PCR analysis, normalized to the internal control GAPDH. HUVECs were treated with LPS (1 $1 \mu \mathrm{g} / \mathrm{mL})$ and different doses of Pd-Ia (10, 20, $40 \mu \mathrm{M})$ for $24 \mathrm{~h}(\mathrm{n}=5)$

significantly downregulated the mRNA level of PPAR- $\gamma$ but no effect was found by Pd-Ia treatment (Figure 3). These results suggested that Pd-Ia specifically upregulates PPAR- $\alpha$ expression. Next, we examined the effect of Pd-Ia on PPAR- $\alpha$ at protein level in LPS-induced HUVECs. Consistent with mRNA expression, Pd-Ia at the concentration of 20 and $40 \mu \mathrm{M}$ dose-dependently upregulated the expression of PPAR- $\alpha$ and the phosphorylation of PPAR- $\alpha$ (p-PPAR- $\alpha$ ), that was downregulated by LPS stimulation (Figure 4), These results suggested that Pd-Ia could upregulate PPAR- $\alpha$ expression and enhance PPAR- $\alpha$ activity in LPSinduced HUVECs.

\section{Anti-inflammatory effects of Pd-Ia on LPS-induced inflammation is PPAR- $\alpha$-dependent}

To further investigate whether the anti-inflammatory effect of PdIa is PPAR- $\alpha$-dependent, the PPAR- $\alpha$ siRNA was used to explore the role of PPAR- $\alpha$ in LPS-induced HUVECs. Our results showed that the PPAR- $\alpha$ siRNA006 was more effective than siRNA005 or siRNA007 to suppress both the mRNA and protein expression of PPAR- $\alpha$ in HUVECs (Figure 5). The knock-down efficiencies of PPAR- $\alpha$ were $50.7 \%$ and $51.3 \%$ as determined by quantitative real-time PCR and western blot analysis, respectively (Figure 5 ). Therefore, we selected PPAR- $\alpha$ siRNA006 in the following experiments. PPAR- $\alpha$ knockdown could significantly increase the mRNA levels of TNF- $\alpha$ and IL- $1 \beta$ that were reduced by $40 \mu \mathrm{M}$ Pd-Ia (Figure 6), suggesting that the anti-inflammatory effect of Pd-Ia on LPS-induce inflammatory response is PPAR- $\alpha$ dependent.
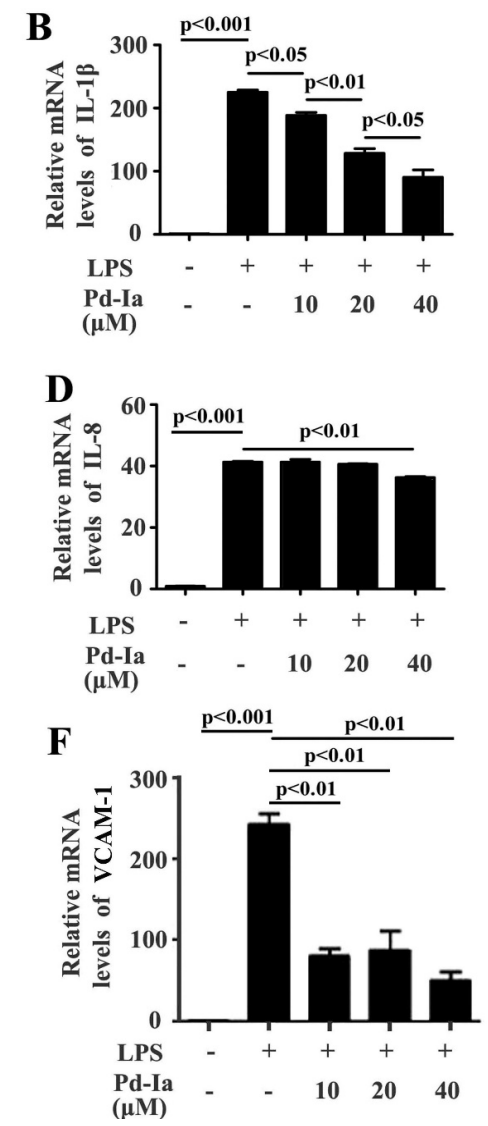
A
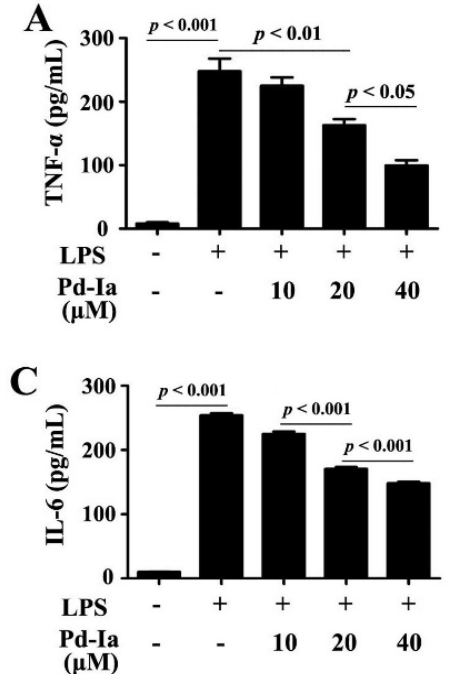
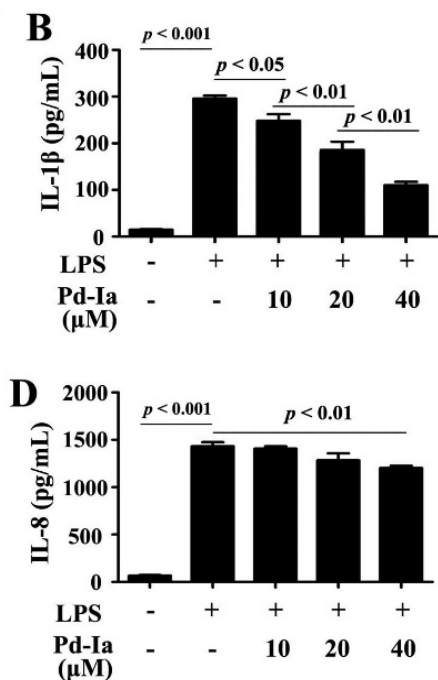

Figure 2. The Protein levels of pro-inflammatory genes in LPS-stimulated HUVECs. (A) The concentrations of TNF- $\alpha$, (B) IL-1 $\beta$, (C) IL-6 and (D) IL-8 in culture supernatants were measured by ELISA analysis. HUVECs were treated with LPS $(1 \mu \mathrm{g} / \mathrm{mL})$ and different doses of Pd-Ia $(10,20,40 \mu \mathrm{M})$ for $24 \mathrm{~h}$ and culture supernatants were collected $(\mathrm{n}=5)$
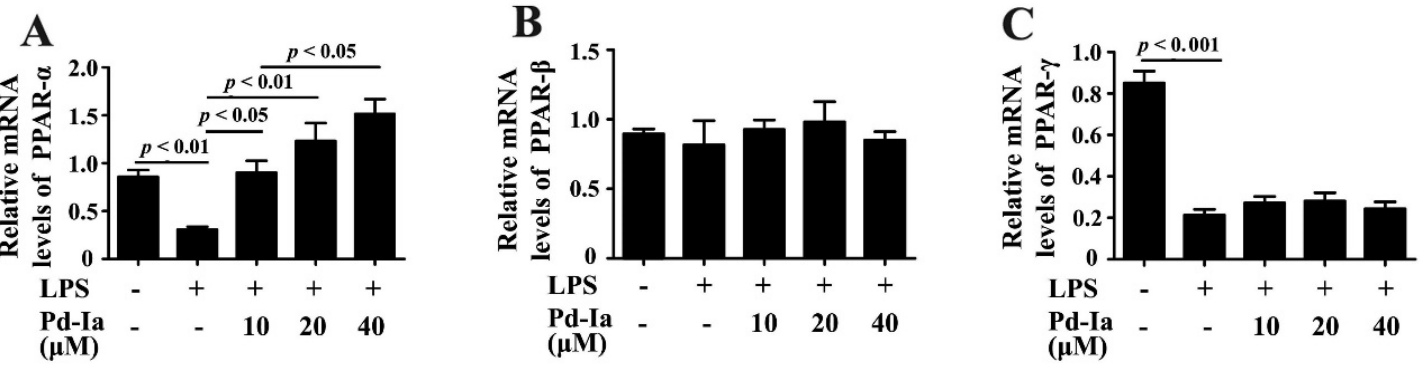

Figure 3. The mRNA expression of PPAR- $\alpha$, PPAR- $\beta$ and PPAR- $\gamma$ in LPS-stimulated HUVECs. (A) The relative mRNA levels of PPAR- $\alpha$, (B) PPAR- $\beta$ and (C) PPAR- $\gamma$ were detected by quantitative real-time PCR analysis, normalized to the internal control GAPDH. HUVECs were treated with LPS $(1 \mu \mathrm{g} / \mathrm{mL})$ and different doses of Pd-Ia $(10,20,40 \mu \mathrm{M})$ for $24 \mathrm{~h}(\mathrm{n}=5)$
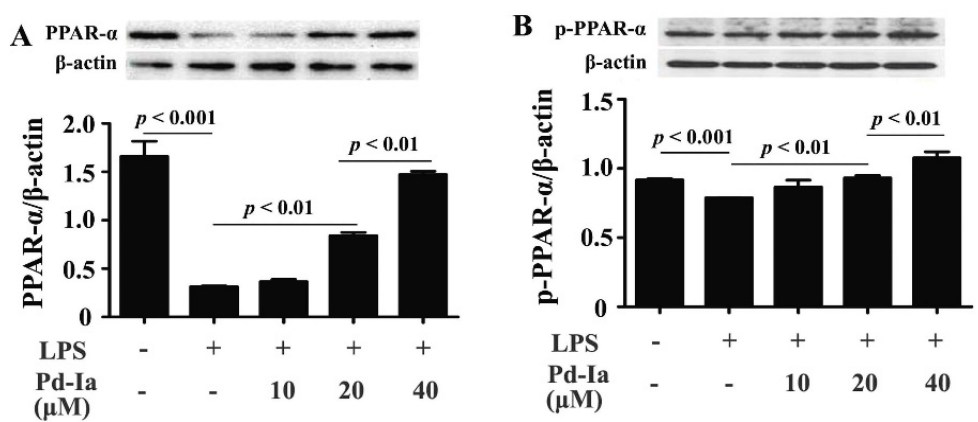

Figure 4. The protein expression of PPAR- $\alpha$ and phosphorylated-PPAR- $\alpha$ (p-PPAR- $\alpha$ ) in LPS-stimulated HUVECs. (A)Western blotting analysis and statistic summary for protein levels of PPAR- $\alpha$ and (B) p-PPAR- $\alpha, \beta$-actin served as internal control group. HUVECs were treated with LPS $(1 \mu \mathrm{g} / \mathrm{mL})$ and different doses of Pd-Ia $(10,20,40 \mu \mathrm{M})$ for $12 \mathrm{~h}(\mathrm{n}=3)$

\section{Pd-Ia inhibits LPS-induced phosphorylation of NF-kB through PPAR- $\alpha$}

NF- $\kappa \mathrm{B}$ has been reported to play an important role in the regulation of inflammatory cytokine production [24]. Accordingly, to evaluate whether NF- $\mathrm{BB}$ is involved in the inhibition of inflammatory responses by $\mathrm{Pd}$-Ia, we investigated the effect of $\mathrm{Pd}-\mathrm{Ia}$ on the phosphorylation of NF- $\kappa B$ p65 (p-NF- $\kappa B$ p65), which is required for the activation of NF- $\kappa$ B. LPS induced the $\mathrm{p}-\mathrm{NF}-\kappa \mathrm{B}$ P65 level began to increase at $15 \mathrm{~min}$, peaked at $60 \mathrm{~min}$ and gradually decreased at 120 min (Figure 7). In contrast, Pd-Ia $(40 \mu \mathrm{M})$ greatly suppressed the LPSinduced increase in the $\mathrm{p}-\mathrm{NF}-\kappa \mathrm{B}$ p 65 from $5 \mathrm{~min}$ to $120 \mathrm{~min}$ (Figure 7). The inhibitory effect of Pd-Ia on the p-NF- $\kappa B$ p 65 was apparently suppressed when the cells were treated with a PPAR- $\alpha$ antagonist MK886 from $5 \mathrm{~min}$ to $120 \mathrm{~min}$ (Figure 7 ). These results suggest that the inhibitory effect of Pd-Ia on the LPS-induced increase in p-NF- $\kappa B$ p65 is through PPAR-a signalling pathway. 

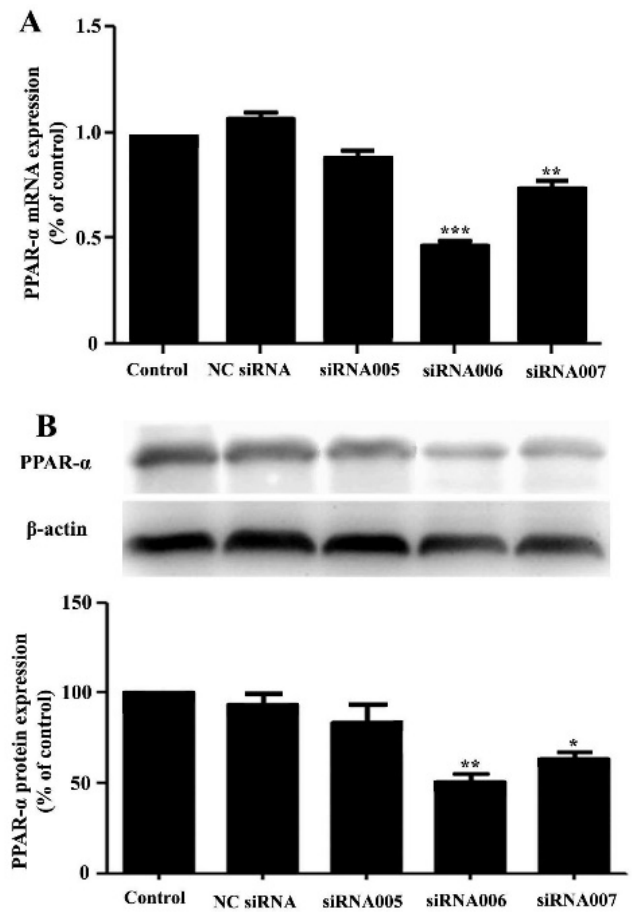

Figure 5. Effect of PPAR- $\alpha$ siRNA on the mRNA and protein expression of PPAR- $\alpha$ in HUVECs. (A) The relative mRNA level of PPAR- $\alpha$ was detected by quantitative real-time PCR analysis, normalized to the internal control GAPDH $(\mathrm{n}=5)$. (B)Western blotting analysis and statistic summary for protein levels of PPAR- $\alpha, \quad \beta$-actin served as internal control group $(\mathrm{n}$ $=3$ ). HUVECs were transient transfected with PPAR- $\alpha$ siRNA $(005,006,007)$ or negative control siRNA (NC siRNA) for $24 \mathrm{~h} .{ }^{*} p<0.05 v s$. NC siRNA, $* * p<0.01 v s$. NC siRNA, $* * * p<$ 0.001 vs. NC siRNA
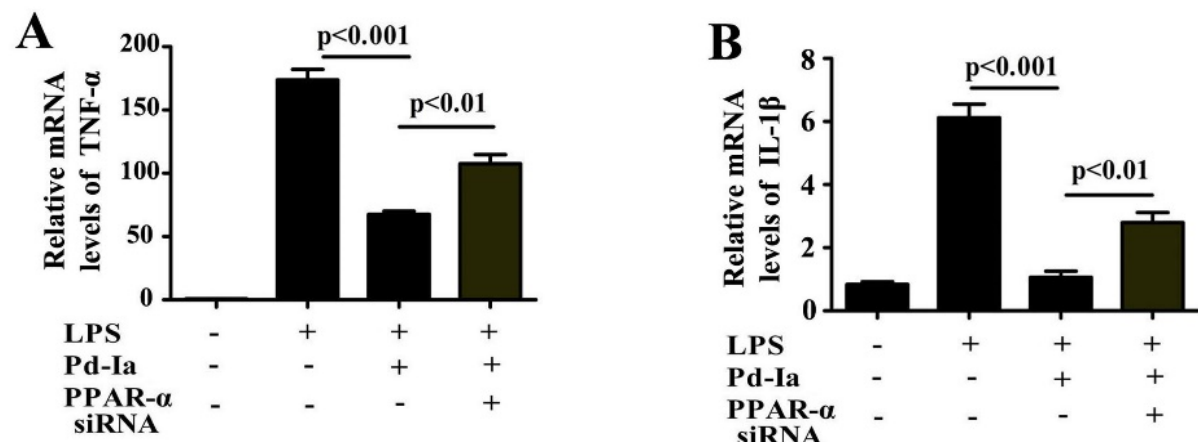

Figure 6. Effect of PPAR- $\alpha$ siRNA on the mRNA expression of pro-inflammatory genes in LPS-stimulated HUVECs. (A) The relative mRNA levels of TNF- $\alpha$ and (B) IL-1 $\beta$ were detected by quantitative real-time PCR analysis, normalized to the internal control GAPDH. HUVECs were treated with LPS $(1 \mu \mathrm{g} / \mathrm{mL})$ and Pd-Ia ( $40 \mu \mathrm{M})$ for $24 \mathrm{~h}$, followed by transient transfected with PPAR- $\alpha$ siRNA (006) or negative control siRNA (NC siRNA) for $24 \mathrm{~h}(\mathrm{n}=5)$
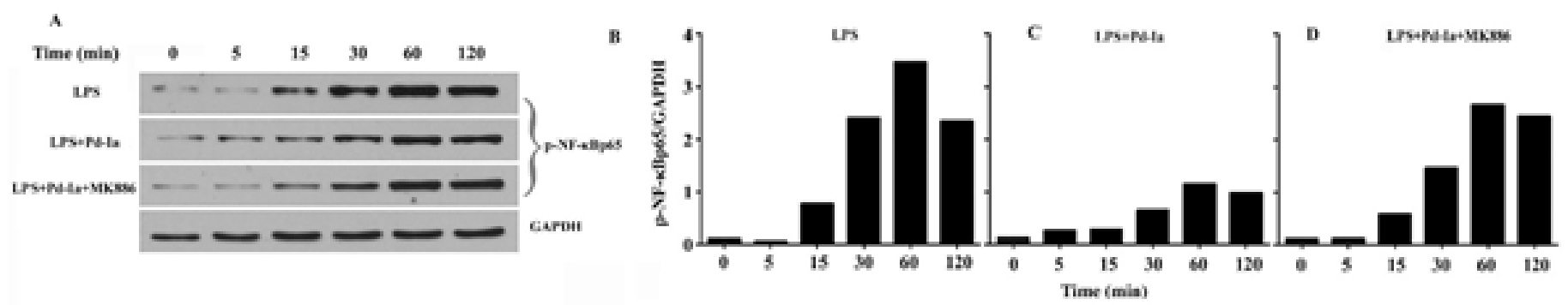

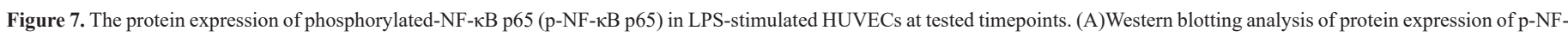
$\kappa B$ p65, GAPDH served as internal control group. (B) HUVECs were treated with LPS $(1 \mu \mathrm{g} / \mathrm{mL})$ alone, (C) HUVECs were treated with LPS (1 $\mu \mathrm{g} / \mathrm{mL})$ and $40 \mu \mathrm{M}$ Pd-Ia, (D) HUVECs were treated with LPS $(1 \mu \mathrm{g} / \mathrm{mL}), 40 \mu \mathrm{M}$ Pd-Ia and $20 \mu \mathrm{M}$ PPAR- $\alpha$ antagonist MK886 


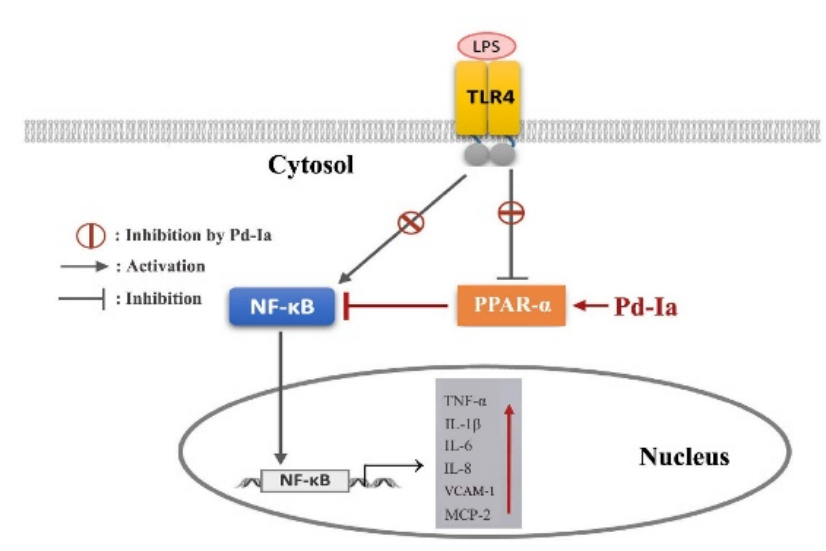

Figure 8. The proposed mechanism underlying the anti-inflammatory role of Pd-Ia in LPSstimulated HUVECs. LPS binds to TLR4 on the surface of the cell, and induces activation $\mathrm{NF}-\kappa \mathrm{B}$ and results in NF- $\mathrm{kB}-$ mediated pro-inflammatory genes expression. On the contrary, Pd-Ia could upregulate PPAR- $\alpha$ expression and enhance its phosphorylation, subsequently inhibiting NF- $\mathrm{KB}$ activity then exerts anti-inflammatory effects

\section{Discussion}

The major finding of this study is that the anti-inflammatory effect of Pd-Ia is due to its ability to activate PPAR- $\alpha$ in LPS-stimulated HUVECs. This can be supported by the following pieces of evidence. First, Pd-Ia selectively upregulated the transcript level of PPAR- $\alpha$ but not that of PPAR- $\beta$ and PPAR- $\gamma$; Second, Pd-Ia increased the protein expression of PPAR- $\alpha$ and enhanced PPAR- $\alpha$ phosphorylation that was reduced by LPS stimulation; Third, PPAR- $\alpha$ siRNA attenuated the inhibitory effect of Pd-Ia on LPS induced expression of TNF- $\alpha$ and IL$1 \beta$, which suggests that the action of Pd-Ia was PPAR- $\alpha$-dependent; Fourth, PPAR- $\alpha$ antagonist MK886 suppressed the effect of Pd-Ia on the LPS-induced phosphorylation of NF- $\kappa B$ p 65.

Some studies have suggested that activation of PPAR- $\alpha$ by its agonists can inhibit LPS-induced pro-inflammatory mediators increase in a variety of cell types, In LPS-stimulated microglia cells, PPAR- $a$ agonists inhibited the secretion of the proinflammatory cytokines IL$1 \beta$, TNF- $\alpha$, IL-6, and IL-12p40 and the chemokine MCP-1 [25]. In the adipocytes, PPAR- $\alpha$ activators suppress the pathogenetical secretion of TNF- $\alpha$ [26]. In activated mesangial cells, LPS treatment induced the significant appearance and substantial activation of PPARa, thus attenuates the proinflammatory response [27]. In endothelial cells, PPAR $\alpha$ acts as a master regulator of inflammation by suppressing TNF- $\alpha$ and IL- 6 expression and involved in inflammatory signalling include NF-kB-dependent pathway [28]. In EAhy926 endothelial cells, PPAR $\alpha$ activators inhibit cytokine-induced nuclear translocation of NF- $\mathrm{KB}$ and expression of VCAM-1 [29]. In the present study, we showed that in LPS-stimulated HUVECs, Pd-Ia suppressed proinflammatory cytokines TNF- $\alpha$, IL- $1 \beta$, IL-6, chemokines IL-8, MCP2 and adhesion molecules VCAM- 1 expression, The inhibitory effect of Pd-Ia was mediated by activation of PPAR- $\alpha$. Whether activation of PPAR- $\alpha$ may be a possible mechanism for anti-inflammatory effect of Pd-Ia in HUVECs, Next we detected the expression of TNF- $\alpha$ and IL$1 \beta$ following Pd-Ia treatment in the presence and absence of PPAR $\alpha$ siRNA, The results showed that interfering PPAR- $\alpha$ attenuate the antiinflammatory effect of Pd-Ia. This may confirmed that inhibiting proinflammatory genes expression by Pd-Ia is associated with PPAR- $\alpha$ pathway.

It is well established that LPS triggers inflammatory responses through the activation NF- $\kappa B$ [30]. NF- $\kappa B$ is a key promoter of inflammation, Once stimulated by LPS, NF- $\kappa \mathrm{B}$ translocate from the cytoplasm to the nucleus where it activates the transcription of pro-inflammatory genes [31,32]. In the present study, our results displayed that Pd-Ia suppressed the expressions of pro-inflammatory genes that were upregulated by LPS in HUVECs. On the other hand, PPAR- $\alpha$ activation has been shown to antagonize the NF- $\kappa B$ signalling pathway, which in turn lead to downregulation of pro-inflammatory cytokines, involved in the vascular inflammation in atherosclerosis [33]. Activation of PPAR- $\alpha$ limits the expression of pro-inflammatory cytokines in atherosclerosis pathological processes [34]. Activation of PPAR- $\alpha$ inhibits inflammatory responses through the TLR4/NF- $\kappa B$ signalling pathway in vascular smooth muscle cells in concert to protect against atherosclerosis [35]. In agreement with these reports, our results showed that Pd-Ia inhibited the LPS induced phosphorylation of NF- $\kappa$ Bp65, which was abolished by PPAR- $\alpha$ antagonist MK886 at tested timepoints. Taken together, all these findings supported that PdIa exert anti-inflammatory effects by activating PPAR- $\alpha$ and inhibiting NF- $\kappa B$ pathway. Here, a schematic diagram was drawn to describe the anti-inflammatory role of Pd-Ia in LPS-induced HUVECs and the underlying mechanisms (Figure 8).

In conclusion, our results demonstrated that Pd-Ia exerted antiinflammatory effects in LPS-induced HUVECs which involves in the activation of PPAR- $\alpha$ and the suppression of NF- $\kappa$ B activity. This may offer a therapeutic strategy for the management of endothelial inflammatory diseases. Further appropriate studies are warranted to evaluate the effect in vivo.

\section{Funding}

This work was supported by the National Natural Science Foundation of China (81270294 to HC; 31270891 to ZQ), Scientific Research Foundation for Advanced Talents, Xiangan Hospital of Xiamen University (NO. PM201809170018 to HC).

\section{Conflicts of interest}

\section{None}

\section{References}

1. Pober JS, Sessa WC (2007) Evolving functions of endothelial cells in inflammation Nat Rev Immunol 7: 803-815. [Crossref]

2. Nomura J, Busso N, Ives A, Matsui C, Tsujimoto S, et al. (2014) Xanthine oxidase inhibition by febuxostat attenuates experimental atherosclerosis in mice. Sci Rep 4 : 4554. [Crossref]

3. Gray SP, Jandeleit-Dahm KA (2015) The role of NADPH oxidase in vascular diseasehypertension, atherosclerosis \& stroke. Curr Pharm Des 21: 5933-5944. [Crossref]

4. Ng HH, Leo CH, Parry LJ, Ritchie RH (2018) Relaxin as a therapeutic target for the cardiovascular complications of diabetes. Front Pharmacol 15: 9: 501.

5. Lin Q, Qin X, Shi M, Qin Z, Meng Y, et al. (2017) Schisandrin B inhibits LPS-induced inflammatory response in human umbilical vein endothelial cells by activating Nrf2. Int Immunopharmacol 49: 142-147. [Crossref]

6. Deng HF, Wang S, Li L, Zhou Q, Guo WB, et al. (2018) Puerarin prevents vascular endothelial injury through suppression of NF-B activation in LPS- challenged human umbilical vein endothelial cells. Biomed Pharmacother 104: 261-267.

7. Monfoulet LE, Mercier S, Bayle D, Tamaian R, Barber-Chamoux N, et al. (2017) Curcumin modulates endothelial permeability and monocyte transendothelial migration by affecting endothelial cell dynamics. Free Radic Biol Med 112: 109-120. [Crossref]

8. Wang Y, Gao Y, Yu W, Jiang Z, Qu J, et al. (2013) Lycopene protects against LPSinduced proinflammatory cytokine cascade in HUVECs. Pharmazie 68: 681-684.

9. Liang Q, Yu F, Cui X, Duan J, Wu Q, et al. (2013) Sparstolonin B suppresses lipopolysaccharide-induced inflammation in human umbilical vein endothelial cells. Arch Pharm Res 36: 890-896. [Crossref] 
10. Zhao NC, Jin WB, Zhang XH, Guan FL, Sun YB, et al. (1999) Relaxant effects of pyranocoumarin compounds isolated from a Chinese medical plant, Bai-Hua Qian$\mathrm{Hu}$, on isolated rabbit tracheas and pulmonary arteries. Biol Pharm Bull 22: 984-987. [Crossref]

11. Song Y, Jing W, Yan R, Wang Y (2015) Research progress of the studies on the roots of Peucedanum praeruptorum dunn (Peucedani radix). Pak J Pharm Sci 28: 71-81. [Crossref]

12. Chang TH, Liu XY, Zhang XH, Wang HL (2002) Effects of dl-praeruptorin A on interleukin-6 level and Fas, bax, bcl-2 protein expression in ischemia-reperfusion myocardium. Acta Pharmacol Sin 23: 769-774. [Crossref]

13. Wang C, Chang TH (2004) Comparative research between Bai-hua Qian-hu, a Chinese traditional plant, and its active ingredient on nuclear factor-kappa and tumor necrosis factor-alpha in isolated ischemia-reperfusion heart of rat. Chin Med J (Engl) 117: 461463. [Crossref]

14. Tu X, Miao L, Kang Y, Xia H, Tu JW, et al. (2009) Effects of dl-praeruptorin A on cultured neonatal rat ventricular cardiomyocytes with hypertrophy induced by endothelin-1. Methods Find Exp Clin Pharmacol 31: 231-236. [Crossref]

15. Berger J, Moller DE (2002) The mechanisms of action of PPARs. Annu Rev Med 53: 409-435. [Crossref]

16. Lefebvre P, Chinetti G, Fruchart JC, Staels B (2006) Sorting out the roles of PPAR alpha in energy metabolism and vascular homeostasis. J Clin Invest 116: 571-580. [Crossref]

17. Hamblin M, Chang L, Fan Y, Zhang J, Chen YE (2009) PPARs and the cardiovascular system. Antioxid Redox Signal 11: 1415-1452.

18. Zandbergen F, Plutzky J (2007) PPARalpha in atherosclerosis and inflammation. Biochim Biophys Acta 1771: 972-982. [Crossref]

19. Briguglio E, Di Paola R, Paterniti I, Mazzon E, Oteri G, et al. (2010) WY-14643, a Potent peroxisome proliferator activator receptor-a ppar-a agonist ameliorates the inflammatory process associated to experimental periodontitis. PPAR Res 2010: 193019. [Crossref]

20. Cuzzocrea S, Di Paola R, Mazzon E, Genovese T, Muia C, et al. (2004) Role of endogenous and exogenous ligands for the peroxisome proliferators activated receptors a (PPAR-a) in the development of inflammatory bowel disease in mice. Lab Invest 84 : 1643-1654. [Crossref]

21. Livak KJ, Schmittgen TD (2001) Analysis of relative gene expression data using realtime quantitative PCR and the 2(-Delta Delta C(T)) method. Methods 25: 402-408. [Crossref]

22. Rizzo G, Fiorucci S (2006) PPARs and other nuclear receptors in inflammation. Curr Opin Pharmacol 6: 421-427. [Crossref]
23. Neher MD, Weckbach S, Huber-Lang MS, Stahel PF (2012) New insights into the role of peroxisome proliferator-activated receptors in regulating the inflammatory response after tissue injury. PPAR Res 2012: 728461. [Crossref]

24. Bhatt D, Ghosh S (2014) Regulation of the NF-?B-Mediated transcription of inflammatory genes. Front Immunol 5: 71.

25. Xu J, Storer PD, Chavis JA, Racke MK, Drew PD (2005) Agonists for the Peroxisome proliferator-activated receptor-alpha and the retinoid $\mathrm{X}$ receptor inhibit inflammatory responses of microglia. J Neurosci Res 81: 403-411. [Crossref]

26. Murakami K, Bujo H, Unoki H, Saito Y (2007) Effect of PPARalpha activation of macrophages on the secretion of inflammatory cytokines in cultured adipocytes. Eur $J$ Pharmacol 561: 206-213. [Crossref]

27. Kono K, Kamijo Y, Hora K, Takahashi K, Higuchi M, et al. (2009) PPAR \{alpha attenuates the proinflammatory response in activated mesangial cells. Am J Physiol Renal Physiol 296: 328-336. [Crossref]

28. Pozzi A, Ibanez MR, Gatica AE, Yang S, Wei S, et al. (2007) Peroxisomal proliferatoractivated receptor-alpha-dependent inhibition of endothelial cell proliferation and tumorigenesis. J Biol Chem 282: 17685-17695.

29. Rival Y, Benéteau N, Taillandier T, Pezet M, Dupont-Passelaigue E, et al. (2002) PPARalpha and PPARdelta activators inhibit cytokine-induced nuclear translocation of NF-kappaB and expression of VCAM-1-1 in EAhy926 endothelial cells. Eur $J$ Pharmacol 435: 143-151. [Crossref]

30. Reddy DB, Reddanna P (2009) Chebulagic acid (CA) attenuates LPS-induced inflammation by suppressing NF-kappaB and MAPK activation in RAW 264.7 macrophages. Biochem Biophys Res Commun 381: 112-117. [Crossref]

31. Wang L, Xu Y, Yu Q, Sun Q, Xu Y, et al. (2014) H-RN, a novel antiangiogenic peptide derived from hepatocyte growth factor inhibits inflammation in vitro and in vivo through PI3K/AKT/IKK/NF-kappaB signal pathway. Biochem Pharmacol 89: 255265

32. Zhang N, Chu ES, Zhang J, Li X, Liang Q, et al. (2014) Peroxisome proliferator activated receptor alpha inhibits hepatocarcinogenesis through mediating NF-kB signaling pathway. Oncotarget 5: 8330-8340. [Crossref]

33. Fernandez AZ (2008) Peroxisome proliferator-activated receptors in the modulation of the immune/inflammatory response in atherosclerosis. PPAR Res 2008: 285842. [Crossref]

34. Marx N, Kehrle B, Kohlhammer K, Grub M, Koenig W, et al. (2002) PPAR activators as antiinflammatory mediators in human $\mathrm{T}$ lymphocytes: implications for atherosclerosis and transplantation-associated arteriosclerosis. Circ Res 90: 703-710. [Crossref]

35. Ji YY, Liu JT, Liu N, Wang ZD, Liu CH (2009) PPARalpha activator fenofibrate modulates angiotensin II-induced inflammatory responses in vascular smooth muscle cells via the TLR4-dependent signalling pathway. Biochem Pharmacol 78: 1186-1197. [Crossref]

Copyright: (C2019 Chang H. This is an open-access article distributed under the terms of the Creative Commons Attribution License, which permits unrestricted use, distribution, and reproduction in any medium, provided the original author and source are credited. 